\title{
16
}

\section{The Role of the Law of the Sea in Marine Spatial Planning}

\author{
Dorota Pyć
}

\section{Introduction}

Once, for our ancestors, the ocean was a link between Heaven and Earth. Nowadays, the World Ocean is a universal and common space for all humanity. It is difficult to assess whether the ocean will divide us in the future or bring us closer together. Undoubtedly, solving the problems of the ocean, its protection and the rational use of its resources requires effective cooperation at a global, regional and national level.

To some, the sound of the ocean may evoke the harmony of the past flowing into the future. In order not to lose our connection with it, marine spatial planning (MSP) for sustainable marine governance should be put into practice following the principles of equity. Well-defined, flexible and transparent instruments of marine sustainable governance at a regional and national level are key tools towards achieving governance goals concerning the global ocean (Kingsbury et al. 2005).

Global ocean governance (GOG) is a highly complex concept (Dorman Mc 2000) on account of the multidimensionality and dynamics of ocean management on a legal, economic and social as well as political and cultural level. Ocean governance can be defined as an integrative concept which nowadays allows us to distinguish a set of global problems related to the World Ocean (Galletti 2015; Pyć 2016).

\section{Pyć $(\bowtie)$}

University of Gdańsk, Gdańsk, Poland

e-mail: dpyc@prawo.ug.edu.pl 
MSP is a practical way to create and implement rational organization in the use of ocean space. It is important to strengthen the interaction between ocean users in accordance with the principles of sustainable development and environmental protection and in connection with the implementation of socio-economic goals (Ehler and Douvere 2009).

The Law of the Sea confirms that it is possible to develop an international legal regime, although the creation of a global regime of the seas and oceans complicates the decentralized nature of the international public law system (Harrison 2011; Pyć 2011). The comprehensive approach expressed in the United Nations Convention on the Law of the Sea (UNCLOS 1982) concerning, inter alia, the protection and preservation of the marine environment, testifies to its constitutional dimension. Taking into account the essence of MSP, the legal norms of UNCLOS — which formulate the obligation to protect and preserve the marine environment-are essentially important. They have already strengthened existing treaty norms and supported solutions developed in the process of creating common law adopted in international practices (Pyć 2011).

\section{Marine Spatial Planning in the Law of the Sea}

\subsection{Propaedeutics of Marine Areas}

The Law of the Sea is one of the oldest areas of international public law that regulates the uses of the World Ocean. The hugely influential work of Hugo Grotius - "the Father of the Law of Nations" - is worth mentioning here as it has significantly impacted the development of the Law of the Sea. Grotius created the paradigm which provides the foundation for the modern Law of the Sea. Claiming an established and important role in the doctrine and jurisdictional practices of the coastal States, Hugo Grotius' paradigm, expressed in Mare Liberum written in 1609 ("The Freedom of the Seas or the Right which belongs to the Dutch to take part in the East Indian Trade"), is still valid today and confirms the fundamental foundations of the Law of the Sea, namely that (1) the coastal States have the right to exercise jurisdiction in their marine spaces and (2) the ocean and its resources beyond national jurisdiction are open to all States.

The Law of the Sea was codified in the 1950s in four Geneva Conventions (the Convention on the Territorial Sea and the Contiguous Zone, the 
Convention on the High Seas, the Convention on Fishing and Conservation of the Living Resources of the High Seas and the Convention on the Continental Shelf) and, afterward, in the UNCLOS. In general, UNCLOS consists of norms regulating the use of the marine environment and its resources in accordance with the norms defining the legal status of different marine spaces, overseeing the fulfilment of the rights and obligations of States in marine areas and providing the basis for creating an ocean governance framework.

The UNCLOS states in its preamble that "the problems of ocean space are closely interrelated and need to be considered as a whole". This statement is an important starting point for discussions on ocean governance and MSP. The preamble to UNCLOS includes a normative justification for recognizing the ecological unity of the World Ocean. This recognition is of great importance for MSP, especially in the adjacent and interacting areas of Exclusive Economic Zones (EEZ) (or the continental shelf) and Areas Beyond National Jurisdiction (ABNJs). The planning of ocean space is the logical advancement of the structuring of obligations and the use of rights granted under UNCLOS as well as a practical tool in assisting State Parties to comply with their obligations. It should be clearly emphasized that UNCLOS does not contain any provisions relating expressis verbis to GOG or MSP.

In relevant literature, the marine environment is presented in a multidimensional way-from the processes taking place at the level of the World Ocean to those of a narrower focus such as habitat, species or genetic resources. The ecological unity of the marine environment implies - in terms of, research needs or applying appropriate management tools - a focus on species, habitats and landscapes and their mutual dependencies. Particularly noteworthy are the provisions of the Convention on the Law of the Sea, which are comprehensive and treat the marine environment from the perspective of ecological unity. The concept of marine environment as it is commonly understood refers to the space of sea water, the air above it and the seabed, all of which include various species of fauna and flora which, in turn, contain various other natural and anthropogenic elements. In practice, the marine environment is an area of economic activity. The World Ocean can be considered a synonym of the marine environment (Pyć 2011).

The term "marine areas" (or marine spaces, marine zones) has a purely conventional meaning in the Law of the Sea. On the basis of their legal status, UNCLOS divides marine areas into three categories: (1) marine areas included in the territory of a State, (2) marine areas which are subject to limited jurisdiction and in which a coastal State enjoys sovereign rights and (3) marine areas located beyond national jurisdiction. The marine areas included in the 
territory of a coastal State are: internal waters (Article 8 UNCLOS), territorial sea, (Article 3-4 UNCLOS) and archipelagic waters (Articles 46-54 UNCLOS).

The internal waters are the waters landward of the baseline of the territorial sea. A coastal State has sovereignty over its internal waters, extending to the air space over the internal waters as well as to their bed and subsoil. Similarly, an archipelagic State has sovereignty over the international waters of the archipelago.

The territorial sea includes a narrow band of water extending seaward from a coastal State's baseline. Every State has the right to establish the breadth of its territorial sea up to a limit which does not exceed 12 nautical miles measured from the baselines. The outer limit of the territorial sea is the line every point of which is at a distance from the nearest point of the baseline equal to the breath of the territorial sea. The external boundary of the territorial sea is the border of the coastal State's territory. The legal status of the territorial sea is subject to the coastal State's sovereign authority which extends to the air space over the territorial sea as well as to its bed and subsoil. Regarding the territorial sea, the legal order of the coastal State is in force. The specificity of the State's maritime territory reflects the compromise resulting from the idea of freedom of the seas, the provision of a number of rights to foreign ships in the territorial sea belonging to the coastal State and the sovereignty and territorial authority of the coastal State over its territorial sea.

The marine areas under limited jurisdiction in which the coastal State has sovereign rights include the EEZ (Articles 55-75 UNCLOS), the continental shelf (Articles 76-85 UNCLOS) and the contiguous zone (Article 33 UNCLOS).

The EEZ is an area beyond and adjacent to the territorial sea which does not extend beyond 200 nautical miles from territorial sea baselines, and it is subject to a special legal status (Article 55 of UNCLOS). Within EEZ, the coastal State has the right to exploit the water column, seabed and subsoil.

The EEZ is not a part of the State territory. The coastal State's rights in those area are functional, not territorial in nature. It is a special, sui generis kind of area which belongs neither to a territorial sea nor to High Seas. While the coastal State has sovereign rights over the resources of the zone and its economic use, it does not exercise sovereignty over the zone itself. Only those rights which, in accordance to the purpose and character of the zone, are related to conducting economic activity in it are qualified as sovereign. The coastal State is not obliged to make these resources available to other States, even if it does not take advantage of them. However, the principle of rational use of living resources, also called the principle of optimal use of living 
resources, stating that if a coastal State cannot obtain all acceptable catches, it should allow other countries to fish within certain limits, still applies.

The sovereign rights granted to the coastal State in the EEZ were limited in two ways. First, the State exercises these rights only for the purpose of exploiting, researching, protecting and managing the natural resources of the zone, and second, when exercising these rights, the coastal State should duly take into account the rights and obligations of other States and should act in accordance with the provisions of the Convention on the Law of the Sea.

The coastal State in the EEZ zone also has jurisdiction in the establishment and use of artificial islands, installations and structures, marine scientific research and the protection of the marine environment. The consequence of the application of the freedom of the seas principle in the EEZ is the application of provisions on the High Seas, provisions which regulate and form part of the legal status of the EEZ, with restrictions resulting from the sovereign rights of coastal States. Freedom of navigation may be limited by the rights of the coastal State in the scope of the marine environment's protection, for example, against pollution from ships. However, these powers do not give the coastal State complete freedom of action. In order to protect the interests of other States, laws and regulations issued to prevent, reduce and control pollution from ships, the coastal State must act in compliance with generally accepted international standards and principles.

UNCLOS provides that in the EEZ the coastal State has jurisdiction with regard to the protection and preservation of the marine environment (Article 56(1)(b)(iii)). In exercising this jurisdiction, the coastal State is empowered to enact laws and regulations for the prevention, reduction and control of vesselsource pollution in the EEZ. In accordance with Article 211(5) of UNCLOS, such laws and regulations must conform to and give effect to generally accepted international rules and standards established through the competent international organizations.

The contiguous zone provides a buffer consisting of an additional 12 nautical miles beyond the territorial sea. Thus, the outer limit of the contiguous zone does not exceed 24 nautical miles from territorial sea baselines. Within this zone, a State has the right to enforce its customs, fiscal, immigration or sanitary laws and regulations within its territory or territorial sea.

Marine ABNJs include the High Seas (Articles 86-115 UNCLOS) and "the Area" (deep seabed, 133-155 UNCLOS). The High Seas is the water column beyond the EEZ. It is neither subject to any sovereign power nor appropriated, open to the common use of all States, in accordance with the principle of freedom of the seas. From a legal standpoint, the High Seas is not subject to the sovereignty of any State and its use is free for all States. The 
principle in force regarding the freedom of the seas, specifically the High Seas, means that all States can use this area. Certainly, the use of the High Seas must be carried out in such a way as not to affect the interests of other States. The High Seas is res usus publicum (Pyć 2011).

The seabed, which is either the continental shelf or "the Area", that is, the seabed and Deep Ocean beyond national jurisdiction, is not a part of the High Seas. The High Seas, however, includes airspace, and all States have the right to rationally use this space. Although subject to certain regulations, within this ocean space, all States have equal rights in terms of essentially enjoying freedom of navigation, freedom of overflight, freedom to lay submarine cables and pipelines, freedom to construct artificial islands and other installations permitted under international law, freedom of fishing and freedom of scientific research (Attard and Mallia 2014).

"The Area" is the seabed, ocean floor and subsoil beyond national jurisdiction and has special legal status. "The Area" and its resources are the common heritage of mankind (CHM). No States shall claim or exercise sovereignty or sovereign rights over any part of "the Area" or its resources, nor shall any State or natural or juridical person appropriate any part thereof. All rights in the resources of "the Area" are vested in mankind as a whole. "The Area" is intended only for the use of peaceful aims. Activities related to exploration and use of "the Areas" are managed by the International Seabed Authority (ISA), a special management unit established for this very purpose. All State Parties to UNCLOS are ipso facto members of the ISA. The ISA is the organization through which State Parties organize and control activities in "the Area”, particularly with a view to administering the latter's resources (Article 133). "The Area" will ensure a fair distribution of benefits to all States, taking into account good faith (e.g. Articles 157 and 300). UNCLOS regulates the issue of "the Area's" legal status under part XI.

\subsection{The Protection and Preservation of the Marine Environment}

For many centuries, the division of the seas and oceans was based on the assumption that marine resources are infinite and, even if not, far greater than humanity's needs. Yet, empirical research confirms the degradation of the World Ocean's ecological condition. Global threats include, inter alia, sea-level rise, accumulation of pollutants in the marine environment, deterioration of the self-cleaning capacity of closed or semi-closed seas, climate change resulting in ocean acidification and overfishing. The results of the negative 
changes affecting seas and oceans accumulate over time and space. The future of humanity depends on the health of the oceans which should translate into a careful maintenance of their natural balance, including biodiversity. When considering the state of the marine environment, it is often emphasized that protection of the marine environment is effective when entities operating in this environment act in accordance with obligations resulting from international laws (Harrison 2017).

The Convention on the Law of the Sea, otherwise known as the "constitution of the seas and oceans", pays special attention to international law on the protection of the marine environment (Franckx 1998). UNCLOS confers the power on coastal States to adopt laws and regulations on the safety of navigation and the regulation of maritime traffic in its territorial sea, in respect to, inter alia, the conservation of the sea's living resources (Article 21(1)(d)), the preservation of the coastal State's environment and the prevention, reduction and control of pollution (Article 21(1)(f)).

UNCLOS refers to the rights and obligations of the participatory States regarding the protection and preservation of the marine environment and the prevention of marine pollution not only in the territorial sea, but also in the EEZ and the High Seas. These provisions should be interpreted alongside those included in Part XII, which deals exclusively with the protection and preservation of the marine environment from different sources of pollution (Molenaar 1998).

In order to prevent, reduce and control pollution, UNCLOS obliges its States to create legal rules, standards and recommendations, both at the global and regional level (Articles 207-208, 210, 212). The agreement refers to the relationship between international regulations and internal legislation (domestic law), with the aim of unifying the law and, as a result, increasing maritime safety and security.

UNCLOS contains legal norms aimed at the effective protection of the marine environment, for example, the obligation of States to prevent transboundary pollution, including pollution from or through the atmosphere, the introduction of the environmental impact assessment, the concept of the protection of marine biological diversity or the creation of marine protected areas (MPAs) (e.g. clearly defined areas, Article 211(6a)). Some of these norms are particularly important for MSP.

The coastal State may adopt special mandatory measures for the prevention of vessel-source pollution in specific clearly defined areas of its EEZ. To justify the adoption of such measures, evidence must indicate that the existing international rules and standards are inadequate for the special circumstances of the area concerned. The area must be "clearly defined" and the adoption of 
special measures must be required for recognized technical reasons regarding the oceanographical and ecological conditions as well as the utilization or protection of the resources and the particular character of the traffic of the area concerned. Article 211(6)(a) and (b) include specific conditions for the adoption of special mandatory measures: the coastal State should conduct appropriate consultations through the competent international organization (e.g. International Maritime Organization (IMO)) with other States concerned. It should also submit a communication to the organization regarding special mandatory measures, supported by scientific and technical evidence and information on reception facilities; the organization, within 12 months of receiving the communication, shall determine whether the conditions in the proposed area justify the adoption of special mandatory measures; following a decision by the organization, the coastal State may adopt laws and regulations implementing such international rules and standards or navigational practices as are made applicable, through the organization, for special areas. These laws shall not apply to foreign vessels until 15 months after the submission of the communication to the organization. The coastal State shall publish the limits of the area where the special mandatory measures are to be enforced.

The coastal State has sovereign rights in the EEZ in the field of exploration and exploitation of natural resources, but these rights should be interpreted in conjunction with the responsibilities for the protection and rational management of these resources. The coastal State acts as "the resource manager" in its EEZ. According to the provisions of the Convention on the Law of the Sea, which concern the living resources of the High Seas and, in particular, highly migratory species, anadromous and catadromous stocks whose protection in UNCLOS has been specifically regulated and referenced in Part XII of UNCLOS, it is clear that its purpose is to protect and preserve the marine environment.

\subsection{Global and Regional Cooperation}

The natural unity of the World Ocean can be protected through the effective cooperation of all actors of the international community. The duty to cooperate is a fundamental norm in the legal context of the marine environment's protection.

Observations from the last decade illustrate the efforts of both the international society (e.g. by international organizations: IMO, Intergovernmental Oceanographic Commission [IOC]) and regional communities to develop and implement solutions using various ocean governance instruments. UNCLOS prescribes that States shall cooperate on a global or regional basis, 
directly or through competent international organizations, in formulating and elaborating international rules, standards and recommended practices and procedures for the protection and preservation of the marine environment, taking into account characteristic regional features (Article 197).

Science-based, integrated, adaptive, strategic and participatory approaches are all core values that the IOC promotes in the context of MSP. With a view towards building the technical and institutional capacities of nations around the world, the IOC integrated its MSP initiative as part of the Integrated Coastal Area Management Strategy that was endorsed by the IOC Assembly in 2011. Since then, the IOC has continued to document the international practice of MSP around the world, synthesizing lessons learnt and updating technical guidance in various aspects of MSP design and implementation. Ten years after the first MSP conference in Paris, the IOC contribution in the MSP field culminated with the organization of the second International Conference on MSP in March 2017 at IOC/United Nations Educational, Scientific, and Cultural Organization (UNESCO) in tandem with the European Commission's Directorate-General for Maritime Affairs and Fisheries (DG Mare). This Conference helped consolidate the international network of MSP practitioners and assessed the contribution of MSP towards sustainable Blue Growth and marine ecosystem conservation, as well as identified priorities for the future of MSP. Also, the IMO cooperates, perhaps not directly on MSP, but in tandem with the Regional Seas Programme of the United Nations Environment Programme (UNEP). In particular, the IMO has played a key role in the establishment of international conventions (e.g. International Convention for the Prevention of Pollution from Ships (MARPOL), International Convention for the Safety of Life at Sea (SOLAS), International Convention for the Control and Management of Ship' Ballast Water and Sediments (BWM), International Convention on the Control of Harmful Anti-fouling Systems on Ships (AFS)), as well as regional arrangements for combating marine pollution (Molenaar 1998). The degree of the international acceptance of the IMO norms, standards and recommended practices is decisive in establishing the extent to which State Parties to UNCLOS are under the obligation to implement them (Harrison 2011). This factor is important, bearing in mind that international shipping has undergone tremendous changes in the last few decades. These changes are related not only to the growing tonnage of the world fleet but also to technical progress and new technologies which are changing the face of the shipping industry. Efforts to introduce even higher standards in terms of the protection of the marine environment, especially through the establishment of obligatory standards for the prevention of marine pollution from ships, are and will be increasingly stronger. The necessity of strong international cooperation and coordination between States is already visible. 
Nowadays, work is being carried out more intensively than ever before on improving the effectiveness of international and regional cooperation for the implementation of GOG as well as MSP objectives (Zaucha 2014). These improvements are aimed at developing the cross-sectoral organization of national work (Kroepelien 2007).

The doctrine indicates the need to continuously improve international cooperation which, in turn, facilitates the development of ocean governance methods. Across the world, within international and non-governmental organizations, researchers in various fields conduct both individual and joint research on changes occurring in the marine environment and the design of instruments necessary for its effective protection (Juda 1996; Friedheim 2000; Kimball 2003).

The ecosystem approach, holistic and integrated, as well as the experience gained from network cooperation at regional levels suggest that the transferring of regional cooperation mechanisms to the global level is possible. Work on global administration and management of the marine environment has already begun. The effectiveness of the legal regime of the Law of the Sea in the protection of the World Ocean depends on the level of commitment and will of the international community.

\section{An Effective Approach to Ocean Governance}

An integrated, interdisciplinary, cross-sectoral and ecosystem approach to ocean governance, in conjunction with the legal framework included in the Convention on the Law of the Sea and the objectives of Chap. 17 of Agenda 21 (Agenda 21), is not only desirable but necessary and of fundamental importance to humanity. The need to introduce integrated management is mentioned, referring especially to the implementation of management at the regional level.

In general, the Law of the Sea refers to maritime human activity, taking into account particular categories of marine areas and their legal status. This approach is referred to as a sectoral approach or zonal approach. In response to the weakness of the sectoral approach, a cross-sectoral approach has been developed. The basis for promoting and implementing the cross-sectoral approach is cooperation, in particular cross-border cooperation (Tanaka 2004; Gilek et al. 2015).

A complete dismissal of the sectoral approach is unreasonable. Instead, the sectoral approach used to solve the problems of the World Ocean should be 
complemented or supported by a holistic and integrated approach to management. The aim of combining the potential of the sectoral approach with the integrated approach in the management of seas and oceans is the identification of environmental problems in the complexity of socio-economic and political conditions and the design of proper solutions. Although the lack of financial resources is generally considered a basic problem, the main barrier is setting priorities when allocating available funds for economic development (global economic policy) with environmental problems pushed into the background (Pyć 2011).

GOG policy, based on integration and coordination, must take into account interdependencies that closely and in a multidimensional way link mankind with the ocean. Striving for effective global and regional cooperation requires integration into functional ocean management, in particular regarding global shipping, the management and protection of endangered species and their habitats, sustainable development of technologies, marine scientific research and tourism. The same applies to global problems: climate change, sea-level rise, reduction of biodiversity, the disposal and storage of hazardous waste at the bottom of the sea and under the seabed. The right approach to ocean governance must reflect the idea of a peaceful use of the seas and the harmonious coexistence of nations regarding the maintenance of international security.

The Manado Ocean Declaration adopted in Indonesia in May 2009 includes important findings for GOG. States have declared their willingness to achieve the long-term conservation, management and sustainable use of living marine resources and coastal habitats through a precautionary and ecosystem approach and to implement long-term strategies with internationally agreed sustainable development goals (SDGs), including those outlined in the UN Millennium Declaration regarding the marine environment, thereby strengthening the global partnership for development. The Declaration stressed the need of implementing national strategies for the sustainable management of coastal and marine ecosystems, in particular mangrove forests, wetlands, grassland clusters, estuaries and coral reefs, protective zones that minimize the negative effects of climate change on one hand and, on the other hand, resources. Countries have also referred to the introduction of integrated coastal zone management and ocean management, including maritime and coastal zoning, in order to minimize and reduce the risk of adverse climate change in coastal communities (critical infrastructure) (Manado Ocean Declaration 2009).

It is worth paying attention to the ten principles of open sea management (10 Principles for High Seas Governance) developed by the International 
Union for Conservation of Nature (IUCN), which are increasingly supported by the literature of the subject and practice. These are conditional freedom of activity on the High Seas, protection and preservation of the marine environment, international cooperation, a science-based approach to management, public availability of information, transparent and open decision-making processes, a precautionary approach, an ecosystem approach, sustainable and equitable use, and responsibility of States as stewards of the global marine environment.

The implementation of the Sustainable Development Goal on Ocean (SDG\#14), which is one of the 17 goals of the UN Agenda for Sustainable Development 2030 and takes into account MSP and generally ecosystembased management, provides an effective framework for guiding the sustainable development of coasts and oceans. The UN's vision regarding MSP is based on the use of interdisciplinary sciences for better policymaking and management, for example, to strengthen socio-economic analysis; plan for the local context- "No one size fits all"; combine single-sector and multi-sector area-based approaches; advance the cross-border use of MSP, integrated coastal zone management (ICZM) and MPAs; harmonize the legal and regulatory frameworks across borders; ensure full benefit sharing among stakeholders; develop practical trade-off analyses for realistic planning; use risk analysis and investment scenarios for the engagement of the private sector.

\section{The Usefulness of Marine Spatial Planning}

The first international meeting devoted to MSP was held in 2007 by the IOC (of UNESCO). Then, as a way of improving the decision-making and implementation process, the definition of MSP was formulated based on an ecosystem approach in managing human activities in the marine environment. The inclusion of MSP in the planning process enables an integrated, forwardlooking and consistent decision-making regarding the use of the sea by humans (Ehler and Douvere 2009).

When addressing the concept of integrated management, two doubts need to be resolved. First, the selection of elements which should be integrated in this approach, and second, the extent to which the foundations of this approach are truly supported by the contemporary international Law of the Sea and the international environmental law. It is commonly accepted that, although there is no unified definition of integrated management in international law, the primary goal of this approach is to effectively solve problems that cannot be effectively addressed using traditional instru- 
ments. In solving the problems of the World Ocean, a certain degree of integration is required, at least on three levels: axiological, normative and functional. The necessity of integrated management is already visible in the axiological dimension through moral obligation and the development of preventive responsibility for marine and normative protection. This requires the implementation of jointly designed standards included in international agreements, providing them with mechanisms of law monitoring and coordination, including improving existing weaknesses resulting from the sectoral approach (Pyć 2011).

MSP has been defined by the IOC (of UNESCO) in 2009 as "a public process of analyzing and allocating the spatial and temporal distribution of human activities in marine areas to achieve ecological, economic, and social objectives that are usually specified through a political process" (Ehler and Douvere 2009).

The IOC guide "Marine Spatial Planning: A Step-by-Step Approach Toward an Ecosystem-Based Management" has been used as the reference document for developing the policy context in the European Union in the Directive 2014/89/EU establishing the framework for MSP (EC 2014).

MSP is a process that aims to reconcile the diverse group of entities in disagreement over terms of interests and expectations. The different legal status of marine areas, the diverse types and effects of human activities in the marine environment, multifaceted activities and measures aimed at the protection and conservation of marine ecosystems, as well as many other related factors amount to a highly complex web which planning has to solve. In practice, the implementation of MSP may be burdened with ballast resulting from the sectoral approach and well-established habits when it comes to designating the competence of the administrative bodies responsible for maritime affairs.

It is worth noting that many coastal States have introduced instruments into their domestic law that are used to manage maritime space, in order to meet the environmental protection obligation laid down in Article 192 of UNCLOS.

Management as a decision-making process is implemented at many levels of an organization, and it is assumed that it ensures the elimination of detected threats, the use of opportunities and the organization's effective fulfilment of all the functions necessary to achieve the set goal (Ehler 2014). Literature pertaining to the field of management uses the term "management by control". In a complex management process, control plays a key role. It is assumed that "there is no management without control". The control activity aims at eliminating, before the end of each stage of a specific process, phenomena that may negatively affect the final result. One should 
take into consideration the following criteria: purposefulness, economy, reliability and legality as well as organizational efficiency, meaning correct and effective directions of action and appropriate means to accomplish set tasks. Control, understood as a fundamental management method, must be based on recognition of the problem's identity and result from a thorough analysis of the problem. This, in turn, may produce a universal and flexible procedure that can be used in different circumstances. This procedure should be easy to interpret, particularly in unpredictable situations.

\section{$5 \quad$ Marine Spatial Planning as a Tool of Integrated Maritime Policy}

MSP is an instrument of maritime policy, both at the national and regional levels. In the Baltic Sea region, the development of common principles pertaining to MSP, such as holistic, ecosystem and precautionary management, is associated with the involvement of all relevant entities and bodies (Zaucha 2014; Backer 2015). MSP in the Baltic Sea is of interest to international organizations and institutions, including the European Union and the Baltic Marine Environmental Protection Commission (HELCOM). The HELCOM Action Plan of 2007 contained a commitment addressed to the State Parties to the Helsinki Convention regarding the Protection of the Marine Environment of the Baltic Sea Area and, more specifically, it required of them the joint development of general cross-sectoral MSP principles based on an ecosystem approach in cooperation with other international bodies.

It is worth noting that the HELCOM-VASAB Joint Group on MSP defined the following ten principles of MSP: sustainable management, an ecosystem approach, long-term perspective, the precautionary principle, participation and transparency, high-quality data and information bases, transnational coordination and consultation, coherent terrestrial and MSP, planning adapted to characteristics and special conditions at different areas and continuous planning.

Marine management is based on MSP decision-making and integrated management, that is, making decisions and constantly improving planning procedures. From a legal point of view, maritime management (the marine environment and its resources) operates within two areas: legal and institutional. For maritime management, the legal aspect, i.e. the substantive and formal normative dimension of law, is as important as the 
institutional level, that is, the executive level, which covers all governmental and non-governmental organizations and international institutions that carry out activities directed at environmental management, or whose activity has specific effects on the environment.

Marine environmental management includes multidimensional and integrated planning of human activity based on the most up-to-date scientific knowledge of ecosystems and their dynamics. It also requires knowledge on any activities that are essential to maintaining ecosystem health, as well as ensuring sustainable use of resources, including maintaining ecosystem integrity and ecosystem services.

The entire management process is essential: from planning, through decision-making, to executing management activities in practice. Management and responsibility for the protection of the marine environment in individual areas should be clearly, consistently, flexibly and comprehensively defined. The precautionary principle and the ecosystem approach determine the current framework for spatial planning in marine areas and regulate various human activities in the marine environment with a view to protecting marine and coastal ecosystems and biological diversity (Söderström 2017; Ansong et al. 2017; Pyć 2017).

This structure will avoid overlapping competences of administrative bodies and other entities (agencies) which set goals for implementation. A great amount of hope relates to monitoring of compliance as an element of more effective law enforcement and an important tool in the effective protection of the World Ocean.

Analysis of the legal status of marine areas confirms the important role of coastal States in creating MPAs and ensuring their effective functioning. All entities of international law are obliged to cooperate in the protection and preservation of the marine environment. The duty to cooperate follows the Convention on the Law of the Sea and is applied to each of the marine areas, including coastal areas. It is strengthened by the provisions of many other international agreements concerning the protection of the environment and natural resources.

An extremely important task is the constant improvement of scientific research regarding the World Ocean. It should be added that building ecological awareness in the community, which consists of explaining the impact of the ocean on people's lives and the impact of human activity on the functioning of the World Ocean and climate, is essential. This type of knowledge translates into more thoughtful behaviour of States, other entities as well as individual people. It allows individuals to participate and make the most 
appropriate and easy-to-implement decisions which will allow for good quality of life with the environment and nature.

The designed MSP framework must include control and surveillance instruments. Marine planners should also be clearly aware of the importance of "marine domain awareness" and the applicable legal norms for the use of the sea. To achieve these objectives, collection of relevant data on the use of the sea is required. MSP procedures, marine environmental control and data collection must meet the requirements of compliance with international law and, from a European perspective, with EU law, both as part of national cooperation with other States as well as at a regional and global level.

Integrated and independent actions introducing solutions to new global problems contrast with the possibilities of existing organizations. Although these institutions seem to be independent, they are characterized by fragmentation and relatively narrow competences as part of their mandates, which leads to the isolation of decision-making processes. Entities responsible for the management of natural resources and environmental protection are institutionally separated from those responsible for economic management. Isolating economic systems from those related to the environment does not support the desired exchanges within the institutions, and the policies pursued by the State are also negatively affected.

Three imperatives for GOG included in the World Commission on Environment and Development (WCED) report of 1987 still retain their relevance. First, the unity of the ocean requires an effective global management system; second, common resources specific to a given sea require a mandatory regional management system; and third, the main threats to the ocean, which originate on land, require effective national actions, undertaken by States and based on the idea of international cooperation (WCED 1987).

Based on the definition of the MSP Directive, MSP involves the identification of possible uses of marine resources and their rational distribution, as well as the provision of sustainable activity in terms of the ecosystem, all of which is performed in the marine environment in order to achieve the economic, social and environmental objectives arising from regional and national policies. These themselves correspond to international rules and standards, recommended practices and procedures for the protection and preservation of the marine environment (Deidun et al. 2011; Santo De 2015).

MSP understood as a purely technical process serves as an instrument of maritime policy at both regional and national level for the implementation of 
the European Union's integrated maritime policy. This policy focuses on an integrated approach to maritime affairs, referring to all available research methods used in the field of identifying and solving problems arising from the use of the sea by humans. The reasoning supporting the introduction of an integrated approach is recognition of the "maritime dimension" and the establishment of a link with the competitiveness of maritime industries and job creation, maritime fisheries and aquaculture, international maritime trade, maritime transport and logistics, access to energy sources, the effects of climate change and counteracting them, ensuring a high level of environmental protection and maintaining biodiversity, marine research and innovations.

\section{Conclusions}

For nearly two decades, there has been a tendency to focus international legal instruments on an integrated approach to ocean governance. GOG includes the way in which the international community sets priorities, goals and systems for the cooperation and coordination of activities within international institutions. The essence of this approach is recognition of the intersection of international, regional and national levels at institutional levels.

Issues related to integrated ocean governance are also clearly derived from international law. Analysing the application of international law instruments leads to the conclusion that even the basic assumptions of the concept of integrated management are arbitrarily interpreted by various interested entities.

The impact of the institutions involved in ocean governance is influenced by the holistic approach adopted in the Convention on the Law of the Sea, which states that "the problems of ocean space are closely interrelated and need be considered as a whole". This one sentence in the preamble to UNCLOS is of particular importance. There are many economic, social, political, as well as scientific factors, among others, which must be considered in the development of policy and law in the context of ocean governance. This particularly applies when formulating principles and specific legal norms for achieving GOG objectives and maintaining their integrity. In addition, the biological diversity of resources is important. Management will need to be carried out with particular attention to biodiversity, not only individually but especially in the context of managing other resources.

International lawyers are considering whether it is possible to design global ocean management programmes at the institutional level based on the assumptions underlying the UNCLOS' concept of mankind's common heritage. The 
introduction of instruments for the management of the seas and oceans has set a new perspective in international law, particularly regarding the Law of the Sea and its practice. The focus has shifted onto the law of the World Ocean as a dialectical system located between a sectoral approach and an integrated approach to managing marine resources. Recognizing that the contemporary Law of the Sea is essentially still based on a sectoral approach, this view exerts a definite influence on interpretive changes in the Law of the Sea. Bearing in mind the achievement of MSP's objectives, from a functional point of view, it is of utmost importance to apply mechanisms of integrated management to the practice of the Law of the Sea in order to create a long-term, reasonable administration of ocean resources in a sustainable manner.

MSP is a process that serves to ensure the introduction of spatial order in seas and oceans. The main goal of MSP is the division of sea space with the purpose of fairly distributing marine areas and their resources between various entities, including coastal States and legal and natural persons. This process may require restrictions on the use of maritime space (e.g. temporary or zonal) and, in justified cases, with the aim of avoiding conflicts between different users of the environment and improving the management of their activities. Capacity building within administrative bodies and other entities in the field of maritime management is also of utmost importance.

MSP is a process which aims to distribute space dynamically for many types of sea use. As such, it also introduces time constraints and even exclusions in order to avoid conflicts between the various users of the environment and improve the management of human activities. MSP should be based on a holistic approach which assumes the existence of multidimensionality and interdependencies of interactions in the marine environment occurring as a result of carrying various activities undertaken in it, including economic activity. In the European Union, specifically those Member States that have developed MSP instruments, the implementation thereof remains at the national level and is carried out by the authorities of those States. The planning process is subject to the analysis of the use of the marine environment and its resources, necessary for decision-making.

Acknowledgements We are grateful to the project "Economy of maritime space" funded by the Polish National Science Centre for contributing the Open Access fee for this chapter and facilitating our discussions and preparation of the book. 


\section{References}

Agenda 21. Retrieved June 16, 2018., from https://sustainabledevelopment.un.org/ content/documents/Agenda21.pdf.

Ansong, J., Gissi, E., \& Calado, H. (2017). An Approach to Ecosystem-based Management in Maritime Spatial Planning Process. Ocean \& Coastal Management, 141, 65-81.

Attard, D., \& Mallia, P. (2014). The High Seas. In D. J. Attard, M. Fitzmaurice, \& N. A M. Gutiérrez (Eds.), The IMLI Manual on International Maritime Law, vol. I: The Law of the Sea (pp. 243-248). Oxford University Press.

Backer, H. (2015). Marine Spatial Planning in the Baltic Sea. In D. Hassan, T. Koukkanen, N. Soininen (Eds.), Transboundary Marine Spatial Planning and International Law (pp. 132-133). Routledge.

Deidun, A., Borg, S., \& Micallef, A. (2011). Making the Case for Marine Spatial Planning in the Maltese Islands. Ocean Development \& International Law, 42(s), 137.

Dorman Mc, T. L. (2000). Global Ocean Governance and International Adjudicative Resolution. Ocean \& Coastal Management, 43, 256.

EC. (2014). Directive 2014/89/EU of the European Parliament and of the Council of 23 July 2014 Establishing a Framework for Maritime Spatial Planning, OJ L 257, 28.8.2014, pp. 135-145.

Ehler, C. (2014). A Guide to Evaluating Marine Spatial Plans. IOC Manuals and Guides No. 70, ICAM Dossier 8. Paris: UNESCO, Intergovernmental Oceanographic Commission UNESCO IOC, 96 pp.

Ehler, C., \& Douvere, F. (2009). Marine Spatial Planning: A Step-by Step Approach Towards Ecosystem-based Management. Manual and Guides No 153 ICAM Dossier No 6. Paris: Intergovernmental Oceanographic Commission UNESCO IOC, 99 pp.

Franckx, E. (1998). Regional Marine Environment Protection Regimes in the Context of UNCLOS. The International Journal of Marine and Coastal Law, 13(3), 310-312.

Friedheim, R. (2000). Designing the Ocean Policy Future: An Essay on How I Am Going To Do That, "Ocean Development \& International Law", pp. 183-195.

Galletti, F. (2015). Transformation in International Law of the Sea: Governance of the "Space" or "Resources"? In A. Maroco, P. Prouzet (Eds), Governance of Seas and Oceans (pp. 2-33). ISTE.

Gilek, M., Hassler, B., \& Jentoft, S. (2015). Marine Environmental Governance in Europe: Problems and Opportunities. In M. Gilek, K. Kern (Eds.), Governing Europe's Marine Environment. Europeanization of Regional Seas or Regionalization of EU Policies? (pp. 255-257) Ashgate.

Grotius, H. The Freedom of the Seas or the Right which belongs to the Dutch to take part in the East Indian Trade, Batoche Books Limited, Kitchener 2000. Retrieved 
June 17, 2018., from https://socialsciences.mcmaster.ca/econ/ugcm/31l3/grotius/ Seas.pdf.

Harrison, J. (2011). Making the Law of the Sea, A Study in the Development of International Law (pp. 238, 257-258). Cambridge.

Harrison, J. (2017). Saving the Oceans Through Law (pp. 17-41). Oxford: The International Legal Framework for Protection of the Marine Environment.

Juda, L. (1996). International Law and Ocean Use Management: The Evolution of Ocean Governance (pp. 285-289). Routledge.

Kimball, L. A. (2003). International Ocean Governance, Using International Law and Organizations to Manage Marine Resources Sustainability (pp. 1-123). Gland: IUCN.

Kingsbury, B., Kirsch, N., \& Stewart, R. B. (2005). The Emergence of Global Administrative Law. Law and Contemporary Problems, 68, 18.

Kroepelien, K. F. (2007). The Norwegian Barents Sea Management Plan and the EC Marine Strategy Directive: Some Political and Legal Challenges with an Ecosystem-Based Approach to the Protection of the European Marine Environment. RECIEL, 16(1), 31.

LEG/MISC/3/Rev.1. Implications of the United Nations Convention on the Law of the Sea for the International Maritime Organization, LEG/MISC/3/Rev.1, 06.01.2003. Retrieved June 17, 2018., from http://www.sjofartsverket.se/ pages/13880/LEG-MISC-3-rev1.pdf.

Manado Ocean Declaration. (2009). Retrieved June 30, 2018, from http://cep.unep. org/manado-ocean-declaration.

Molenaar, E. J. (1998). Coastal State Jurisdiction Vessel-Source Pollution. Kluwer Law International pp., 25-27, 103-110.

Pyć, D. (2011). Prawo Oceanu Światowego (pp. 97-105). Gdańsk: Res usus publicum.

Pyć, D. (2016). Global Ocean Governance. TransNav-The International Journal on Marine Navigation and Safety of Sea Transportation, 10(1), 159-162.

Pyć, D. 2017. The Polish Legal Regime on Marine Spatial Planning, Maritime Law of the Polish Academy of Science (vol. XXXIII). Gdańsk.

Santo De, E. (2015). The Marine Strategy Framework Directive as a Catalyst for Maritime Spatial Planning: Internal Dimensions and Institutional Tensions. In M. Gilek \& K. Kern (Eds.), Governing Europe's Marine Environment. Europeanization of Regional Seas or Regionalization of EU Policies? (p. 95). Ashgate.

Söderström, S. (2017). Regional Environmental Governance and Avenues for the Ecosystem Approach to Management in the Baltic Sea Area. Linköping.

Tanaka, Y. (2004). Zonal and Integrated Management Approaches to Ocean Governance: Reflections on a Dual Approach I International Law of the Sea. The International Journal of Marine and Coastal Law, 19, 453-514. 
UNCLOS. (1982). The United Nations Convention on the Law of the Sea. Retrieved June 16, 2018, from http://www.un.org/depts/los/convention_agreements/texts/ unclos/unclos_e.pdf.

WCED. (1987). Retrieved June 30, 2018, from http://www.un-documents.net/ourcommon-future.pdf.

Zaucha, J. (2014). Sea Basin Maritime Spatial Planning: A Case Study of the Baltic Sea Region and Poland. Marine Policy, 50, 34-45.

Open Access This chapter is licensed under the terms of the Creative Commons Attribution 4.0 International License (http://creativecommons.org/licenses/by/4.0/), which permits use, sharing, adaptation, distribution and reproduction in any medium or format, as long as you give appropriate credit to the original author(s) and the source, provide a link to the Creative Commons licence and indicate if changes were made.

The images or other third party material in this chapter are included in the chapter's Creative Commons licence, unless indicated otherwise in a credit line to the material. If material is not included in the chapter's Creative Commons licence and your intended use is not permitted by statutory regulation or exceeds the permitted use, you will need to obtain permission directly from the copyright holder. 